\title{
The Role of the Corporate Income Tax as an Automatic Stabilizer
}

\author{
Thiess Buettner \\ Clemens Fuest
}

CESIFO WORKING PAPER NO. 2798

CATEGORY 1: PUBLIC FINANCE

SEPTEMBER 2009

\author{
An electronic version of the paper may be downloaded \\ - from the SSRN website: \\ - from the RePEc website: \\ - from the CESifo website: \\ www.SSRN.com \\ www.RePEc.org \\ www.CESifo-group.org/wp
}




\title{
The Role of the Corporate Income Tax as an Automatic Stabilizer
}

\begin{abstract}
This paper analyses the effectiveness of the corporate income tax as an automatic stabilizer. It employs a unique firm-level dataset of German manufacturers combining financial statements with firm-specific information about credit market restrictions. The results show that approximately 20 per cent of all firms report both positive taxable income and capital market restrictions. Taking account of the income tax rates and the size differences of the firms, we find that demand stabilization through the corporate income tax amounts to about 8 per cent of an initial shock to gross revenues. This stabilization effect varies over the business cycle and tends to increase during cyclical downturns.
\end{abstract}

JEL Code: H25, H32, E63.

Keywords: corporate income tax, stabilization, capital market restrictions, loss offset, firmlevel data.

Thiess Buettner

Ifo Institute for Economic Research at the University of Munich

Poschingerstrasse 5

81679 Munich

Germany

buettner@ifo.de
Clemens Fuest

Centre for Business Taxation

Said Business School

University of Oxford

Park End Street

UK - Oxford OX1 HP

clemens.fuest@sbs.ox.ac.uk

September 2009 


\section{Introduction}

The current economic crisis has given rise to a debate on the role of fiscal policy as a factor stabilizing demand and, ultimately, employment and output. There are essentially two ways in which fiscal policy can contribute to demand stabilization: firstly, governments may cut taxes or increase expenditure; secondly, governments may rely on automatic stabilizers. Auerbach and Feenberg (2000) define automatic stabilizers as 'those elements of fiscal policy that tend to mitigate output fluctuations without any explicit government action' (ibid., p.37).

How do automatic stabilizers work? To make things simple, consider an economy with a proportional income tax with a rate of 30 per cent. The effectiveness of the income tax as an automatic stabilizer depends on two factors. The first factor is how a given shock on gross income affects after tax income. In our example, a decline in income by 100 Euros leads to a decline in net income by 70 Euros. This implies that the income tax has absorbed 30 per cent of the initial shock to gross income. The second factor is the link between current disposable income and demand. In the case of private households, current expenditure on consumption goods usually diverges from current disposable income as households try to smooth consumption over time. But if households have no financial wealth and cannot borrow, their current expenditures will largely be determined by their disposable income. In the case of firms, decisions on current expenditures for investment goods and other inputs will be determined by capital costs and expectations about the profitability of investment, rather than current cash flow, which depends on the results of past investment. But firms may also lack financial reserves and face borrowing constraints. As a result, a cushioning of shocks to current cash flow may stabilize their demand, too.

This paper analyses the effectiveness of the corporate income tax as an automatic stabilizer. Usually, the debate about automatic stabilizers focuses on the personal income tax. This is because the income tax is more important in terms of the tax revenue it generates and because it is progressive. We focus on the corporate income tax for a number of reasons. Firstly, the base of the corporate income tax is smaller than that of the personal income tax, but its volatility over the business cycle is much higher. Its potential contribution to 
overall automatic stabilization may therefore be more significant than its share in tax revenue suggests. Secondly, the automatic stabilization properties of the corporate tax raise some policy issues, in particular the role of intertemporal loss offset, which are less pressing in the context of the personal income tax. Thirdly, the role of the corporate income tax for automatic stabilization has been largely neglected in the literature.

With few exceptions, the literature on automatic stabilizers focuses either on the personal income tax, social insurance contributions and benefits (see e.g. Auerbach and Feenberg (2000), Auerbach (2009), Mabbett and Schelkle (2007), Dolls et al. (2009)), or on the tax system as an aggregate (Sachs and Sala-i-Martin (2002), Bayoumi and Masson (1995)), so that the specific issue of corporate taxation plays no role. The role of the corporate income tax as an automatic stabilizer is discussed in Devereux and Fuest (2009). ${ }^{1}$ They suggest a simple method to measure the automatic stabilization effect of the corporate income tax, building on the concept of normalized tax change introduced by Pechman (1973). The normalized tax change relates the cushioning effect of the tax system to the size of the initial shock to gross income. In the simple example used above, the normalized tax change is equal to 30 per cent. Essentially, Devereux and Fuest (2009) start from the fact that the corporate income tax is largely proportional in most countries, so that the normalized tax change would be equal to the tax rate. But if taxable income falls below zero, any cushioning of shocks to gross income disappears unless losses can be carried back to earlier periods. In most corporate tax systems, this is either impossible or highly restricted. Firms may be able to use loss carryforwards in future periods, but this does not stabilize current cash flow. Given this, a stabilizing effect of the corporate income tax can only emerge in firms which have two characteristics: they must be credit constrained and their current taxable income must be positive. Applying this approach to data for UK firms, Devereux and Fuest (2009) find that the corporate tax is largely ineffective as an automatic stabilizer. On average, the demand stabilization through the corporate income tax in the UK is equal to only 1 per cent of the initial shock to gross income. In the presence of full loss offset, the stabilization effect would have been equal to 8.5 per cent.

\footnotetext{
${ }^{1}$ Auerbach and Feenberg (2000) also discuss the role of the corporate tax as an automatic stabilizer but do not produce any estimates. Their focus is on the U.S. federal income tax.
} 
The present paper extends the literature as follows. It is an important limitation of the analysis in Devereux and Fuest (2009) that firm specific information on credit constraints and profit or loss positions comes from two separate and unconnected data sources. The share of firms with both credit constraints and positive taxable income is, therefore, approximated by assuming that all firms with losses also face credit constraints. As a consequence, stabilization effects could only emerge if the number of credit constrained firms exceeds that of loss making firms. This approach underestimates the stabilization effects of the corporate tax as soon as there are firms which run tax losses but do not face credit constraints. In addition, size differences across firms cannot be taken into account. Our analysis is based on a new dataset of German manufacturing firms which combines firm specific information on capital market restrictions with financial information about the firms. This allows us to provide a much more detailed picture of the prevalence of tax losses and financing constraints among firms. Thus, we are able to provide more precise estimates on the effectiveness of the corporate tax to act as an automatic stabilizer.

Our analysis leads to the following results. Most importantly, we find that, in the period from 2003-2007, where detailed data is available, biannually, approximately 20 per cent of all firms report both positive taxable income and credit constraints. Given the German corporate income tax rate of approximately 38 per cent, and taking account of the size differences of the firms, we find that demand stabilization through the corporate income tax amounts to about 8 per cent of the initial shock to gross revenues. Yet a binary regression analysis reveals that the firms reporting credit constraints and positive profits differ from other firms. Besides size differences, we find that firms with a bad business situation are overrepresented among these firms. This casts doubt on the view that these firms would indeed use all available funds for additional investment. Therefore, the estimate of 8 per cent is probably an upper bound for the average stabilization effect.

Another important result of our analysis is that the stabilization effect changes systematically over the business cycle. Since the share of firms with positive taxable income is procyclical whereas the share of firms with credit constraints is anticyclical, it is unclear, a priori, whether the stabilization effect is pro- or anticyclical. In our dataset, it turns out that the change in credit constraints over the cycle dominates: Our sample starts in 2003, when Germany 
was in the middle of a severe economic downturn. For April 2003, our stabilization measure is equal to approximately 13 per cent. In the following periods, Germany experienced an upswing, and the stabilization measure declines continuously to reach a value below 3 per cent in August 2007.

The rest of the paper is set up as follows. In section 2, we discuss the key factors which determine the automatic stabilization effect of the corporate income tax and we derive the measure of automatic stabilization we use for the empirical analysis. Section 3 includes the empirical analysis. Section 4 summarizes the results and concludes.

\section{Firms and Automatic Stabilization Effects of the Corporate Income Tax}

Consider a firm without capital market restrictions. Ignoring risk, this firm would invest in the capital stock if the expected return on capital investment exceeds that of an alternative investment say government bonds. Under standard assumptions, this decision is not affected by the return on past investment. Hence, a shock to the firm's revenues would not affect the investment of the firm. A firm, however, that is facing capital market restrictions, is likely to respond to a revenue shock. As this firm would use internal funds to finance its investment, partly or fully, a shock to current revenues translates into changes in the investment decision. For this firm, a cushioning of revenue shocks due to the corporate income tax is important and will help to smooth investment spending.

If the firm that experiences an adverse revenue shock still makes profits, it benefits from a decline of tax payments in a proportion corresponding to the statutory tax rate. However, if the firm makes losses, the degree to which revenue shocks to firms are cushioned through corporate income taxation depends on the treatment of losses (Auerbach and Feenberg, 2000, Devereux and Fuest, 2009). In an ideal case, where all losses can be carried back to some previous periods with positive profits, cushioning of revenues is symmetric. A firm facing a loss would benefit from a reimbursement of previous tax payments in the same proportion as 
a firm with positive profits. However, in the more realistic case, where loss carry backs are restricted, the corporate income tax does not exert much, perhaps no cushioning of revenue shocks to a firm that incurs tax losses. This suggests that the existence of positive taxable profits constitutes a second qualification to a stabilizing role of the corporation tax.

How can the cushioning effect of the tax system be measured? In this paper, we use a simple measure of the cushioning effect, building on Auerbach and Feenberg (2000) and Devereux and Fuest (2009). Consider an economy with $n$ firms. The cash flow of firm $i$ in period $t$ is given by

$$
C F_{i t}=R_{i t}-C_{t}^{f}-T_{t}\left(R_{i t}, D_{i t}, .\right)
$$

where $R_{i t}$ denotes the firm's revenue net of marginal costs in period $t, C_{t}^{f}$ denotes fixed costs, $D_{i t}$ denotes deductions from the tax base related to fixed costs like e.g. interest on debt or depreciation of capital goods, and $T_{t}($.$) is the firm's current corporate income tax payment.$ Note that the firm's income tax payment may depend on a number of variables, including taxable profits of past periods. Assume that there is a shock on $R_{i t}$, denoted by $d R_{i t}$. The effect on the firm's cash flow is given by

$$
d C F_{i t}=d R_{i t}\left(1-\frac{\partial T_{t}\left(R_{i t}, D_{i t}, .\right)}{\partial R_{i t}}\right)
$$

Equation (2) shows that the impact of an exogenous revenue shock $d R_{t i}$ on the firm's cash flow is mitigated by the tax system if current tax payments change as a result of the decline in revenue and, hence, taxable profits. Of course, current tax payments of firms not only depend on current revenues but usually also depend on past taxable profits and other predictors of current profits, depending on the rules for tax prepayments. However, as a first approximation, the analysis below assumes that $\frac{\partial T_{t}\left(R_{i t}, D_{i t} . .\right)}{\partial R_{i t}}$ is equal to the statutory corporate income tax rate, denoted by $\tau_{t}$, if taxable profits are positive and equal to zero for loss making firms. The stabilizing effect of the corporate income tax system on the cash flow of all firms in the economy in period $\mathrm{t}\left(A_{t}^{C F}\right)$ can be defined as the difference between the cash flow effect which would occur in the absence of taxes and the cash flow effect in the presence of taxes, divided by the overall revenue shock: 


$$
A_{t}^{C F} \equiv \frac{\sum_{i=1}^{n_{t}} d R_{i t}-\sum_{i=1}^{n_{t}} d C F_{i t}}{\sum_{i=1}^{n_{t}} d R_{i t}}
$$

As pointed out above, the stabilization of cash flows does not necessarily lead to a stabilization of investment demand. This can only be expected from liquidity constrained firms. Among these firms, only firms with positive taxable profits will be affected by automatic stabilizers. Denote the number of firms with both credit constraints and positive profits in period $t$ with $m_{t}<n_{t}$, and order firms such that these firms have lower index values $j$. The aggregate effect of automatic stabilizers on investment demand can then be written as

$$
A_{t}^{D} \equiv \frac{\tau_{t} \sum_{j=1}^{m_{t}} d R_{j t}}{\sum_{i=1}^{n_{t}} d R_{i t}}
$$

If the shocks which hit profitable credit constrained firms and other firms are, on average, of equal size, i.e. if

$$
\frac{1}{m_{t}} \sum_{j=1}^{m_{t}} d R_{j t}=\frac{1}{n_{t}} \sum_{i=1}^{n_{t}} d R_{i t},
$$

the demand cushioning effect can be written as

$$
A_{t}^{D}=\tau_{t} \frac{m_{t}}{n_{t}} .
$$

In the following, we will use data for German firms to measure the stabilizing effect of the corporate income tax for the case of Germany.

\section{Empirical Application}

What arises from the considerations in the preceding section is that the potentially stabilizing role of the corporation tax varies with the share of firms that are subject to capital market restrictions and, at the same time, profitable in the sense that their taxable income is positive. Now, this share is likely to change over the business cycle. Actually, it proves anticyclical. This can be seen from Figures 1 and 2 which plot the Ifo Credit Constraint Indicator for 
Figure 1: Credit Constraint Indicator vs. Business Climate

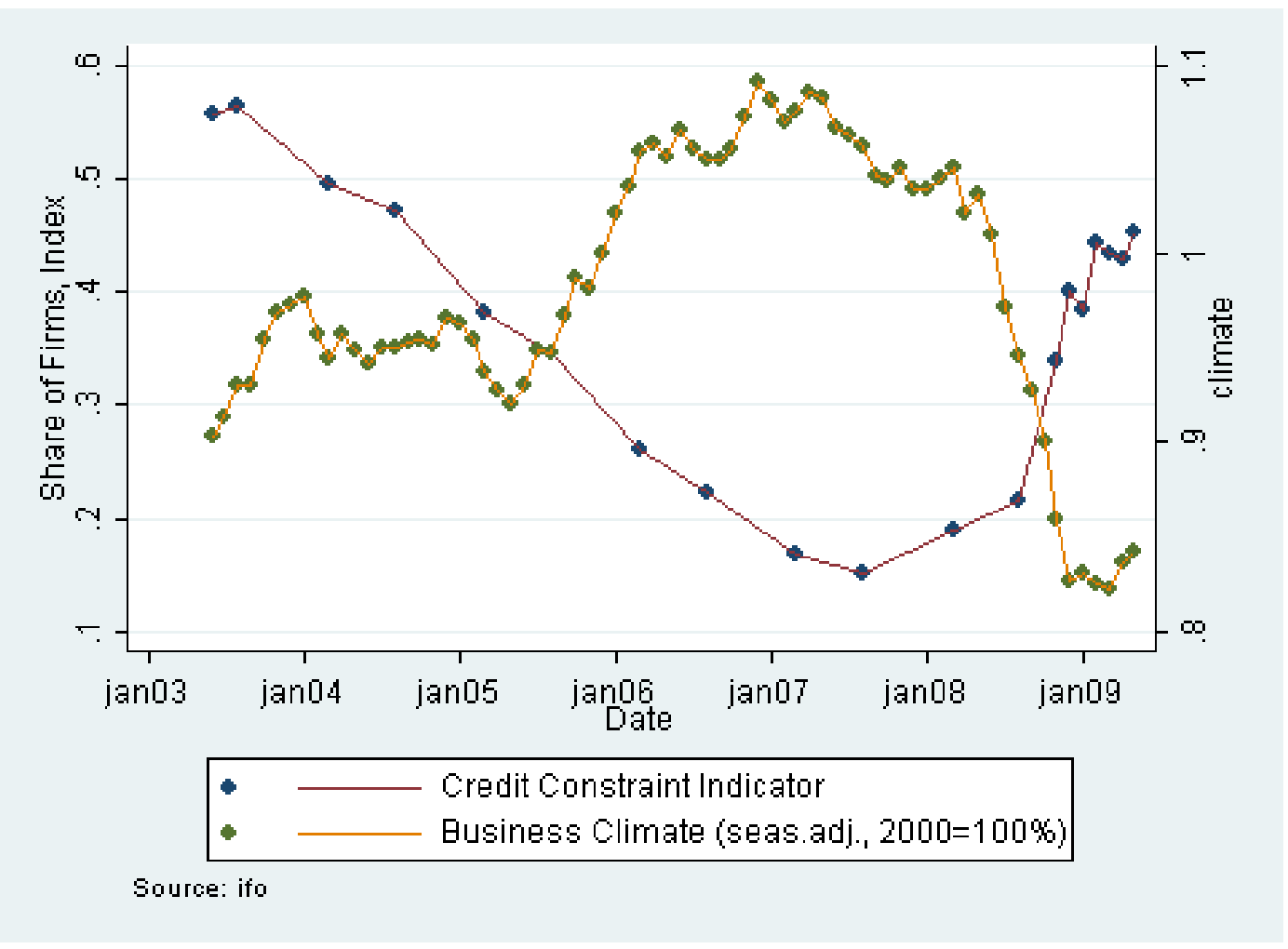

the German economy ${ }^{2}$ against the ifo Business Climate Indicator or the degree of capacity utilization (taken from the ifo Business Survey).

To provide empirical evidence we take resort to a unique dataset for German firms that combines firm-specific information about business situation, capacity utilization, and capital market restrictions with financial information about these firms - including profit and loss statements. The data are supplied by the Economics and Business Data Center (EBDC) in Munich. ${ }^{3}$ For the purpose of the current analysis we focus on ten waves of the data where information about capital market restrictions is provided, starting with June 2003 until August 2007.

\footnotetext{
${ }^{2}$ Until 2007 twice a year, the Ifo Business Survey asks firms about their assessments of bank lending policies. The firms are asked to respond to the following question: "How would you assess the current willingness of banks to extend credit to business"? The Credit Constraint Indicator is calculated from the percentage of the responses in the category "restrictive" (alternative categories are "accommodating" and "normal").

${ }^{3} \mathrm{~A}$ data description is available at: http://www.cesifo-group.de/link/_EBDC_database
} 
Figure 2: Credit Constraint Indicator vs. Capacity Utilization

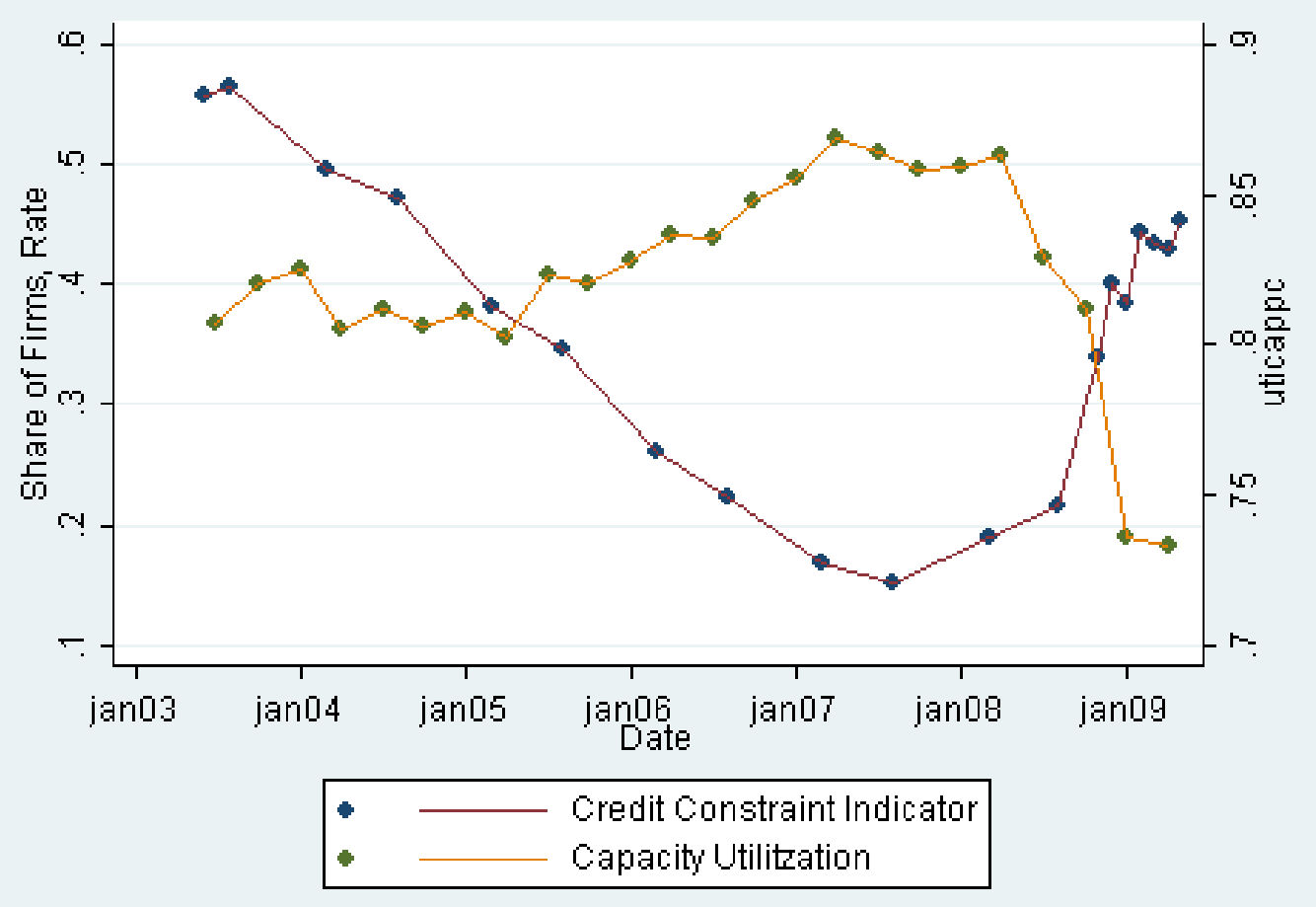

Source: ifo 
Figure 3: Credit Constraint Indicator vs. Share of Restricted Firms in EBDC Database

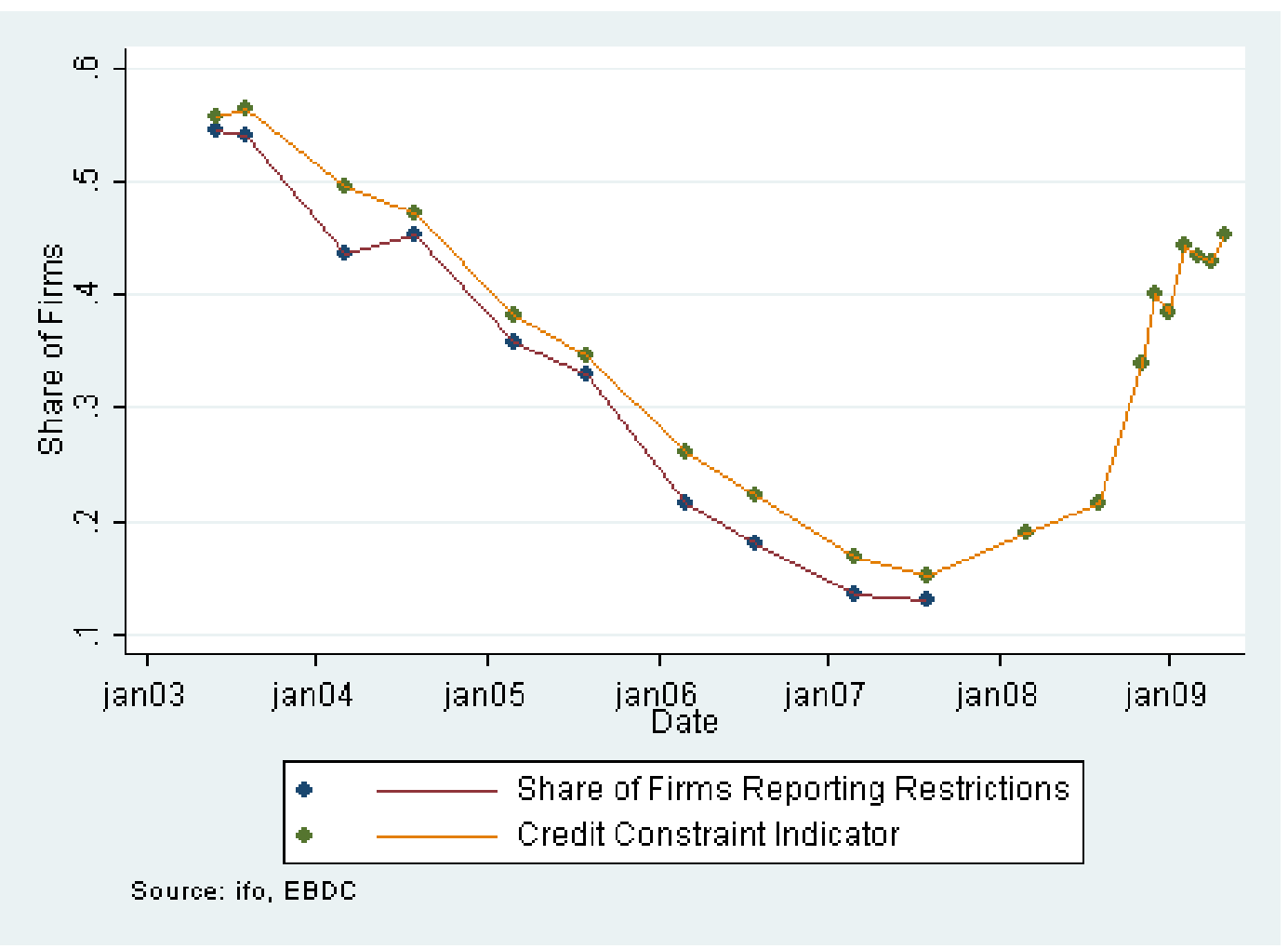

Since the EBDC data used in the study is a subset of the ifo Business Survey where financial information from the Amadeus database has been merged we might be worried about whether this subsample is representative of the ifo Business Survey used in Figures 1 and 2. Figure 3 plots the ifo Credit Constraint Indicator for the manufacturing industry against the share of the firms in our data that consider bank lending policies as restrictive. ${ }^{4}$ The figure shows that the EBDC data on credit constraints provides a reasonably good approximation of the general trend in the ifo Business Survey. ${ }^{5}$

Empirical evidence on the importance of losses is provided by Figure 4. It includes not only the share of firms reporting capital market restrictions but also the share of firms that

\footnotetext{
${ }^{4}$ Following the practice of the ifo Credit Constraint Indicator a firm is considered credit constrained in our analysis if the appraisal of bank lending policies is "restrictive" rather than "accommodating" and "normal".

${ }^{5}$ While rather new, the ifo Business Survey's information on credit constraints is widely used to assess capital market restrictions in Germany (e.g., Bundesbank, 2008). A recent micro-level study exploiting the ifo Business Survey's question on credit constraints (vonKalckreuth, 2008) finds a significant association with firm-level investment policies similar to results based on the Industrial Trends Survey by the Confederation of British Industry (vonKalckreuth, 2006).
} 
Figure 4: Share of Restricted Firms vs. Share of Firms with Losses

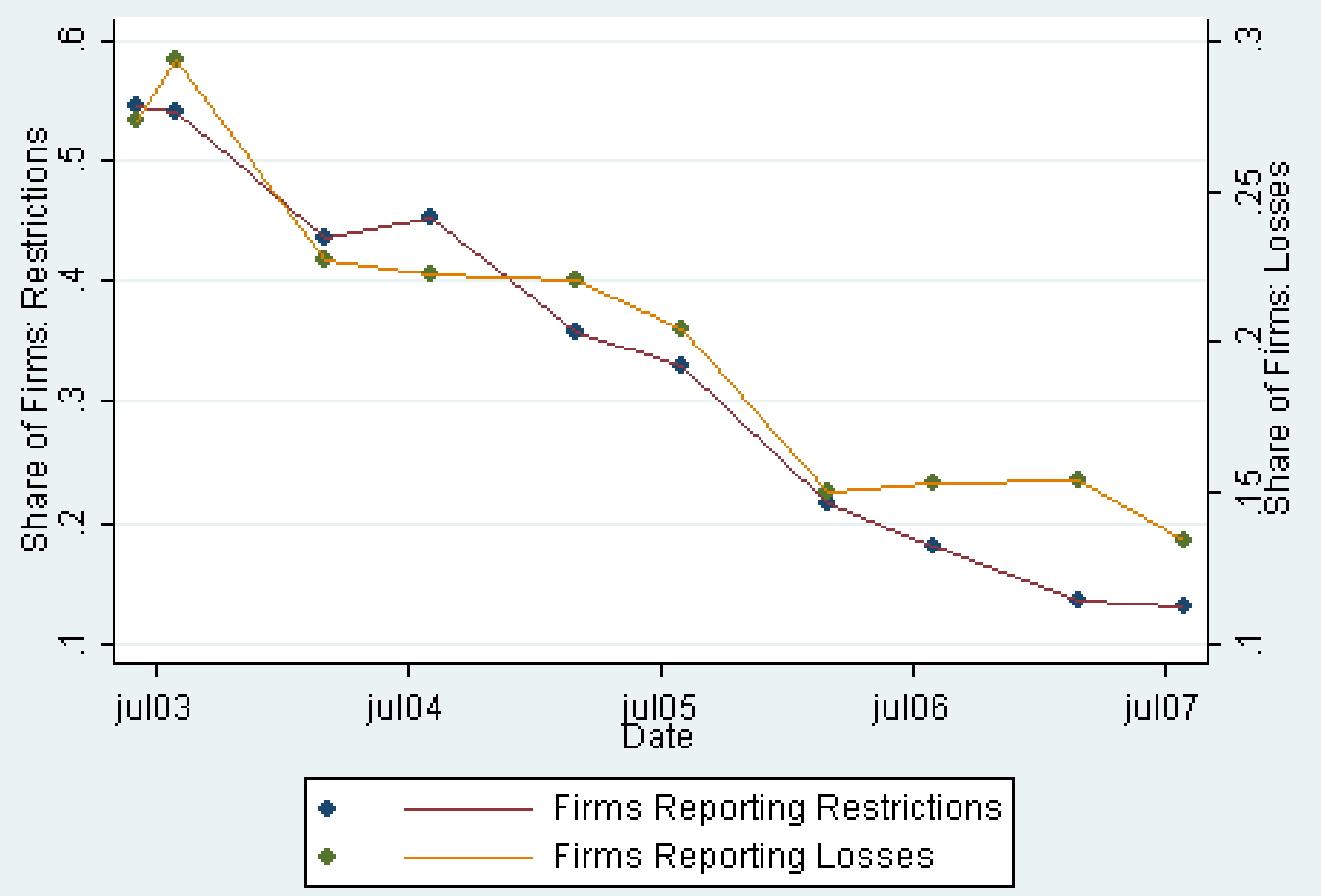

Source: EBDC, combining ifo and Amadeus 
Figure 5: Share of Restricted Firms with Positive Profits

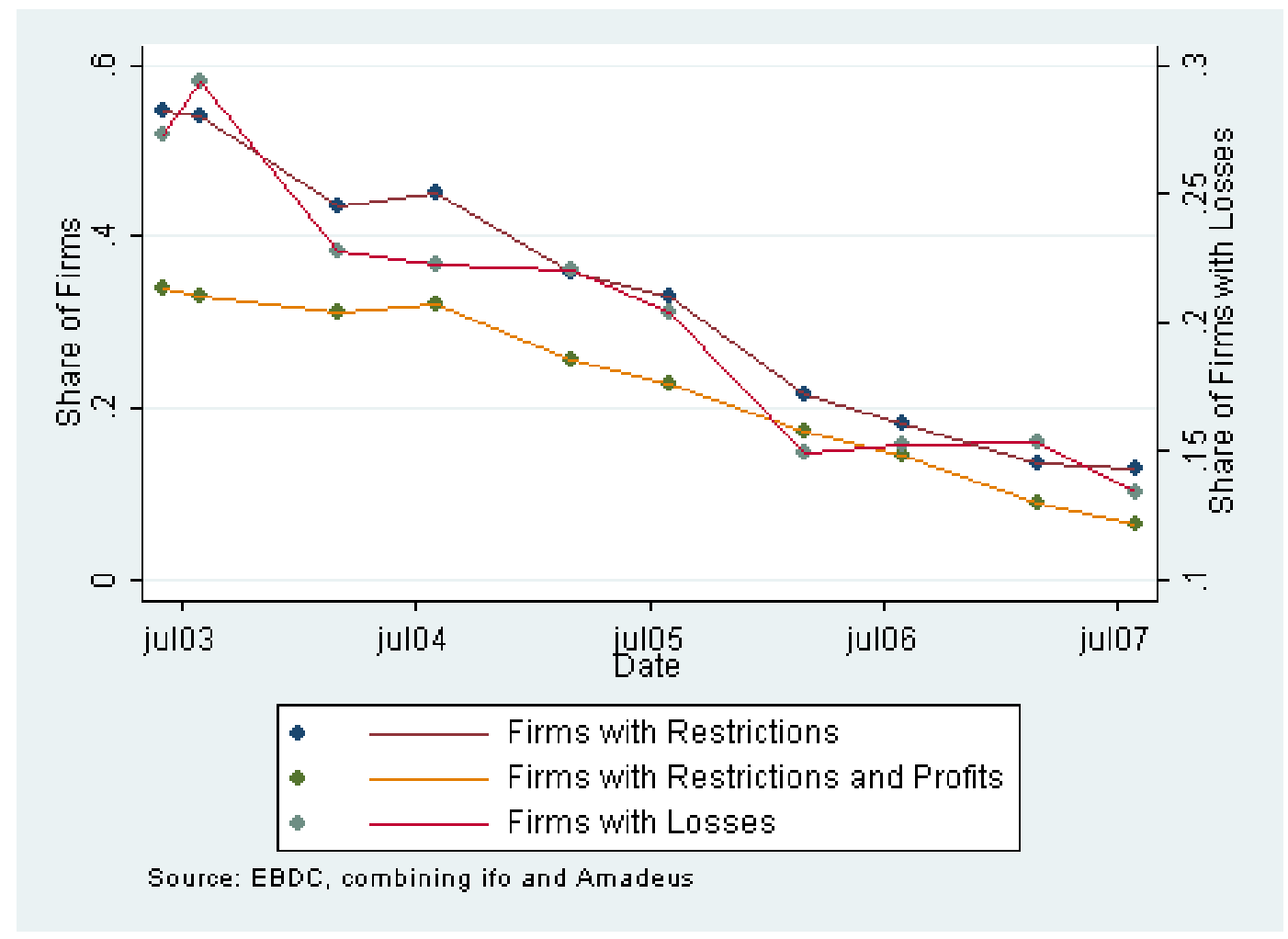

experience losses. The share of firms reporting capital market restrictions is generally twice as large as the share of firms with tax losses (note that the share of firms with losses is reported on the vertical axis at the right-hand side). Remarkably, this relationship proves rather robust across the different time periods.

The descriptive statistics presented so far suggest that the stabilizing effect is subject to different cyclical effects. On the one hand, the share of firms where (net-) revenues are exerting an impact on investment due to capital market restrictions is anticyclical. On the other hand, the share of firms where net-revenues could potentially be smoothed by the corporate income tax due to positive taxable profits is procyclical. Thus, the question arises whether, due to the lack of loss offset, the stabilizing effect of the corporation tax is rather weak in downturns when it would be most important. However, whether this is the case depends on the cyclicality of the joint distribution of losses and credit constraints. 
Evidence is provided by Figure 5 which shows the share of firms that are reporting capital market restrictions but still report positive profits (in the above notation, the figure depicts $\left.\frac{m_{t}}{n_{t}}\right)$. This group of firms will not only adjust their investment expenditures to the availability of internal funds. They are also in the position to benefit from a stabilization of revenues due to the corporation tax. As it turns out, this group of firms on average makes up a fifth of all firms (axis is on the left hand side), indicating that the stabilizing role of the corporation tax is much smaller than indicated by the share of restricted firms.

To sum up, with regard to the role of taxes as automatic stabilizers, our results suggest that over the ten waves of the ifo Business Survey that provide information about capital market restrictions the corporate income tax acted as a stabilizer of investment in a fifth of the German firms, on average. This share, however, is higher in the beginning of the time period, when the economy suffered from a low degree of capacity utilization and when the business conditions were rather weak. Later, when the business situation improved, the share is much lower. A closer inspection of the cyclical pattern reveals two countervailing effects: the share of firms that face capital market restrictions, which, therefore, tend to adjust investment spending to net revenues, is increasing in cyclical downturns. At the same time, the higher likelihood of losses during downturns tends to offset a possibly stabilizing role of the tax system. Yet the net effect points at a stronger role of the corporate income tax as a stabilizer during downturns.

The role of the corporate income tax needs to be further qualified, however, since it seems likely that the firms where a smoothing of investment might take place are firms that are small or are struggling from bad business perspectives. In the former case, demand effects might be unimportant, in the latter case, firms might have reason to cut down on investment spending, anyway.

Figure 6 depicts results for a simple binary regression testing whether specific firm characteristics have significant effects on the probability to jointly report capital market restrictions and positive profits. Figure 7 provides descriptive statistics. While the dummies for the waves depict the time pattern noticed above, the size-range (szrg) and the age of the firm show significant inverse effects. This is in accordance with standard results in the literature on credit 
Figure 6: Characteristics of Restricted Firms with Positive Profits

\begin{tabular}{|c|c|c|c|c|c|c|}
\hline restprof & coef. & $\begin{array}{l}\text { Robust } \\
\text { std. Err. }\end{array}$ & $\mathrm{t}$ & $P>|t|$ & [95\% conf. & Interval \\
\hline statebus & .0289721 & .0110906 & 2.61 & 0.009 & .0072268 & .0507174 \\
\hline szrg & -.0368194 & .0061029 & -6.03 & 0.000 & -.0487853 & -.0248534 \\
\hline pub_q & -.0628211 & .0249556 & -2.52 & 0.012 & -.1117512 & -.013891 \\
\hline age & -.0005937 & .0002057 & -2.89 & 0.004 & -.000997 & -.0001904 \\
\hline tangible & -.0303425 & .0374341 & -0.81 & 0.418 & -.1037391 & .0430542 \\
\hline _Iwave_2 & -.0096717 & .039161 & -0.25 & 0.805 & -.0864541 & .0671108 \\
\hline -Iwave_3 & -.035282 & .0359132 & -0.98 & 0.326 & -.1056966 & .0351326 \\
\hline _Iwave_4 & -.0211418 & .0361548 & -0.58 & 0.559 & -.0920301 & .0497464 \\
\hline _Iwave_5 & -.0909626 & .0345497 & -2.63 & 0.009 & -.1587038 & -.0232213 \\
\hline _Iwave_6 & -.1233893 & .0345764 & -3.57 & 0.000 & -.1911829 & -.0555957 \\
\hline _Iwave_7 & -.1691588 & .0360917 & -4.69 & 0.000 & -.2399234 & -.0983941 \\
\hline _Iwave_8 & -.1965932 & .0360611 & -5.45 & 0.000 & -.2672978 & -.1258887 \\
\hline _Iwave_9 & -.2481623 & .0336922 & -7.37 & 0.000 & -.3142222 & -.1821024 \\
\hline Iwave_10 & -.2705421 & .0326676 & -8.28 & 0.000 & -.3345932 & -.2064911 \\
\hline _cons & .4309728 & .0444439 & 9.70 & 0.000 & .3438322 & .5181134 \\
\hline
\end{tabular}

Figure 7: Descriptive Statistics

\begin{tabular}{|c|c|c|c|c|c|}
\hline Variable & obs & Mean & std. Dev. & Min & \\
\hline $\begin{array}{c}\text { statebus } \\
\text { szrg }\end{array}$ & $\begin{array}{l}3291 \\
3291\end{array}$ & $\begin{array}{l}1.955637 \\
2.815254\end{array}$ & $\begin{array}{r}.670599 \\
1.212357\end{array}$ & $\begin{array}{l}1 \\
1\end{array}$ & $\begin{array}{l}3 \\
5\end{array}$ \\
\hline $\begin{array}{r}5 z r g \\
\text { pub_g }\end{array}$ & $\begin{array}{l}3291 \\
3291\end{array}$ & $\begin{array}{l}2.815254 \\
.0680644\end{array}$ & $\begin{array}{l}1.212357 \\
.2518947\end{array}$ & $\begin{array}{l}1 \\
0\end{array}$ & 1 \\
\hline age & 3291 & 43.83197 & 36.33759 & 1 & 107 \\
\hline tangibie & 3291 & .2853577 & .1977559 & 0 & .9377039 \\
\hline restprof & 3291 & .2403525 & .4273624 & 0 & 1 \\
\hline
\end{tabular}


Figure 8: Weighted Share of Restricted Firms with Positive Profits

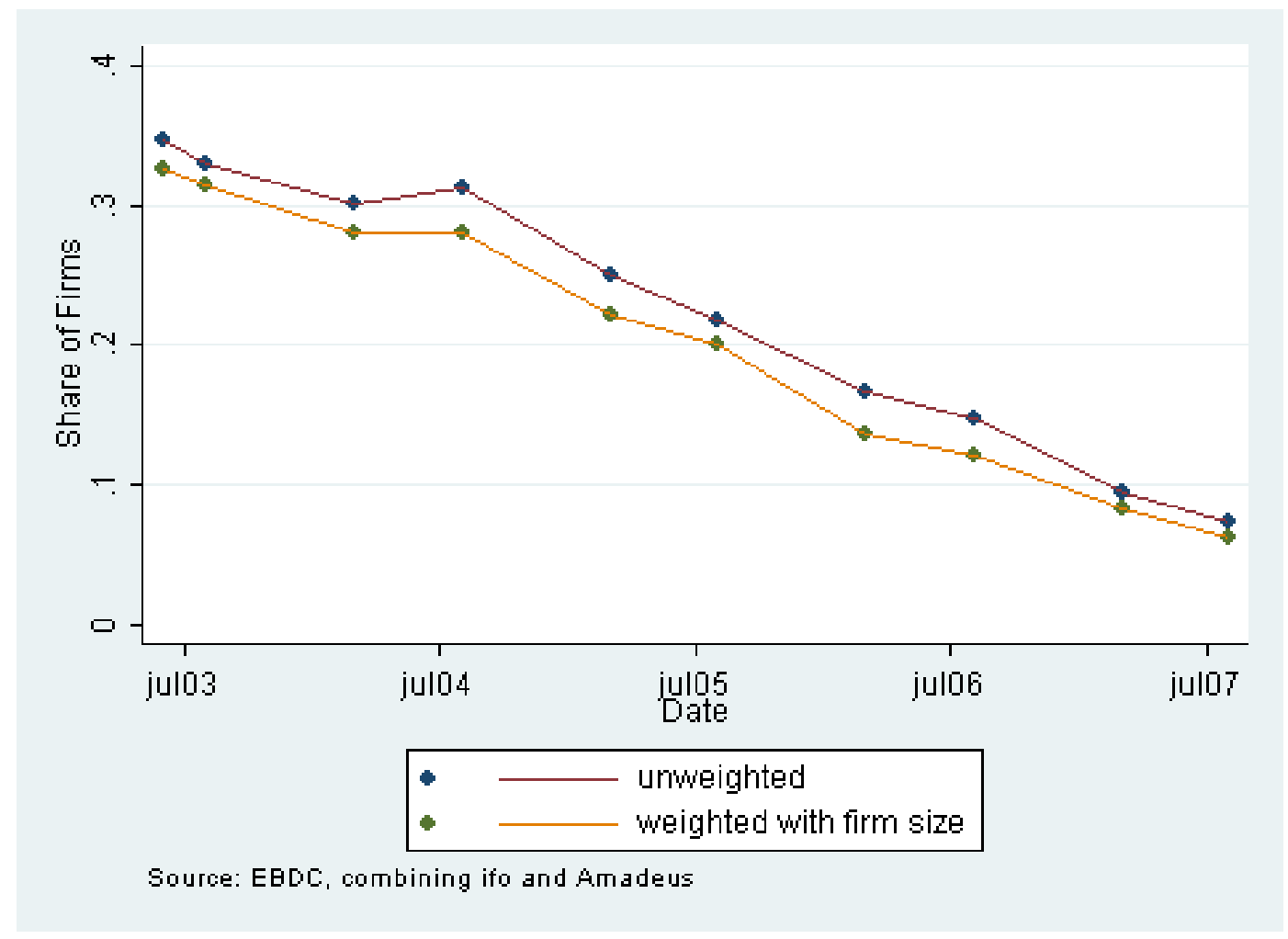

rationing. Also publicly quoted firms depict an inverse effect. However, tangibility does not prove significant. The appraisal of the current business situation by the firm (statebus) shows a positive effect. Note that this categorial variable varies between 1 (good) and 3 (bad). Hence, the positive effect shows that firms with a bad business situation are overrepresented among the group of restricted firms with positive profits. However, the firm's size shows a much stronger effect. This suggests that in an assessment of the role of the corporation tax as an automatic stabilizer we should take resort to statistics weighted by firm size in order to assess the importance of firms that are restricted in terms of credit but report positive profits. Figure 8 documents that the share of these firms weighted by employment (using the size variable szrg) is somewhat lower indeed.

Based on individual firm data, Figure 9 reports an aggregate measure of stabilization corresponding to Equation 6. This measure is obtained as a weighted sum of the statutory tax rates for all firms where a positive profit as well as credit constraints are reported and zero 
Figure 9: Measure of Stabilization

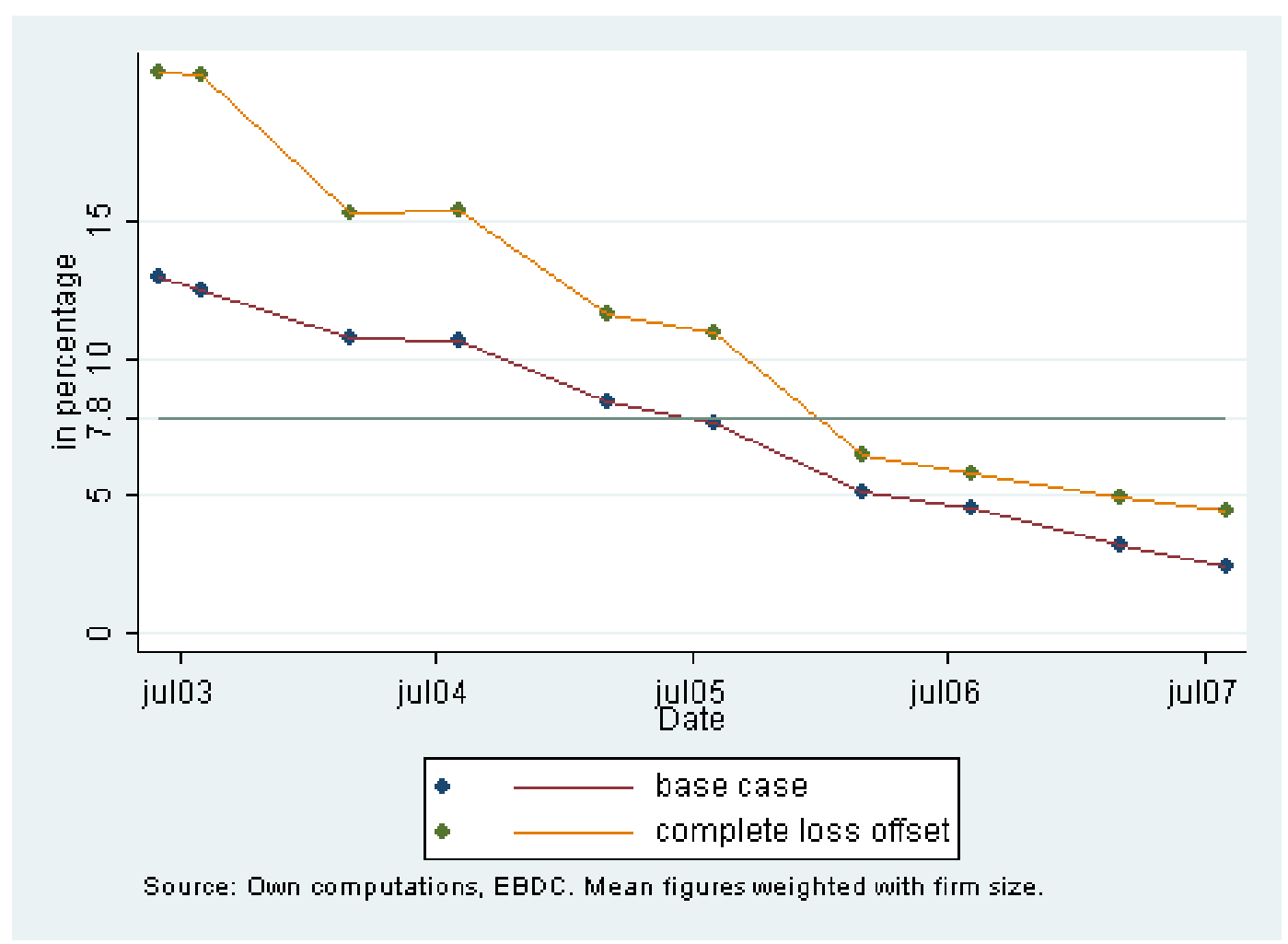

for all other firms. ${ }^{6}$ As can be seen from the figure, the average measure of stabilization is about $7.8 \%$. For comparison, in the hypothetical case with complete loss-offset opportunities where all restricted firms benefit from a stabilization of net-revenues, the average measure would be higher: according to our estimates the mean figure would be about $11.5 \%$.

The figure also shows that the stabilizing effect of corporate income taxation changes systematically over the business cycle. In June 2003, when Germany was in a downturn the stabilization measure is equal to approximately 13 per cent. In the following periods, Germany experienced an upswing, and the stabilization measure declines continuously and reaches a value below 3 per cent for August 2007.

\footnotetext{
${ }^{6}$ Note that we compute the firm specific tax rates taking account not only of the corporation tax and the solidarity surcharge but also of the local business tax rate faced by each firm.
} 


\section{Conclusions}

Using ten waves of a survey of German manufacturing firms, we find that, on average, about 20 per cent of all firms reported both positive taxable income and the existence of credit constraints. Accordingly, at tax rates of approximately 38 per cent, and taking account of the size differences of the firms, demand stabilization through the corporate income tax would amount to about 8 per cent of the initial shock to gross revenues.

While the data used in the above analysis offers a unique combination of firm specific information about credit market restrictions and financial statements, the empirical magnitudes presented are subject to uncertainties. The micro-level evidence rests on financial statement and survey data that captures the conditions faced by the firm only by approximation. The financial statements might differ from the tax accounts and also do not provide information about the existence of tax shields such as loss carry-forwards. Also the survey data on credit constraints should be considered with caution, since the distinction of the different response categories might be somewhat fuzzy. Besides measurement issues, the evidence about the level of stabilization needs to be qualified in a number of ways. First, this estimate is probably providing an upper bound of the stabilizing effect since loss making firms and firms facing credit constraints may constitute a non-representative group of firms. Indeed, our analysis reveals that the firms reporting credit constraints and positive profits are smaller than the average. We, therefore, weight the data with firm-size in order to calculate the above aggregate measure of the stabilization effect. We also find that firms with a bad business situation are overrepresented among these firms. Hence, the willingness of these firms to invest might be low.

Our results also suggest that the stabilizing effect of corporate income taxation changes systematically over the business cycle. While stabilization effects are mainly expected to occur for firms with positive taxable incomes that are also facing credit constraints, our data suggests that the likelihood to report positive taxable income is procyclical whereas the likelihood of credit constraints is anticyclical. In our dataset, it turns out that the change in credit constraints over the cycle dominates such that the effectiveness of the corporate tax as an 
automatic stabilizer tends to increase during cyclical downturns. Of course, the time period considered is rather short, so it would be interesting to reconsider the evidence in future research.

Can we expect our results, which have been derived with German data, to apply to other countries as well? Most European countries have lower statutory corporate tax rates, so that the potential for stabilization effects is lower. But it might be the case that other countries, in particular countries with lower GDP per capita and less developed capital markets, exhibit a larger share of credit constrained firms. This would suggest a stronger effect on demand stabilization.

What are the policy implications of the analysis in this paper? One immediate implication is that our analysis highlights a cost of crowding back loss offset provisions, in particular loss carryback possibilities: restricting loss offset reduces the automatic stabilization effects of the tax system. Of course, extending loss offset would come at a cost in terms of revenue raised, and the question is whether the benefits in terms of automatic stabilization properties of the tax system justify this. The benefits of automatic stabilization through the corporate tax system depend on a number of factors. One issue is whether demand stabilization, if it works, also stabilizes domestic output. If firms import investment goods or intermediate inputs, part of the demand stabilization achieved by automatic stabilizers will leak to other countries. The existence of multinational firms may be another reason why the benefits of automatic stabilization may be limited. These firms may well use the cash flow generated in one country to finance investment in another country. These are interesting issues for future research.

\section{References}

Auerbach, A.J. and D. Feenberg (2000), The significance of federal taxes as automatic stabilizers, Journal of Economic Perspectives 14.3, 37-56.

Auerbach, A.J. (2009), Implementing the new fiscal policy activism, American Economic 
Review, Papers and Proceedings 99, 543-549.

Bayoumi, T. and P. Masson (1995), Fiscal Flows in the United States and Canada: Lessons for Monetary Union in Europe, European Economic Review 39, 253-274.

Bundesbank (2008), Financing Constraints and Capital Accumulation: Microeconometric Evidence, Monthly Report, October, 59-68.

Devereux, M. and C. Fuest (2009), Is the Corporation Tax an Effective Automatic Stabilizer?, forthcoming, National Tax Journal.

Dolls, M., C. Fuest and A. Peichl (2009), Automatic Stabilizers and Economic Crisis: Europe vs. U.S., IZA Discussion Paper 4310.

Mabbett, D. and W. Schelkle (2007), Bringing Macroeconomics back to the political economy of reform: the Lisbon Agenda and the 'fiscal philosophy' of the EU, Journal of Common market Studies 45, 81-104.

Pechman, J. (1973), Responsiveness of the federal Income tax to changes in income, Brookings Papers on Economic Activity 2, 385-421.

Sachs, J. and X. Sala-i-Martin (1992), Fiscal Federalism and Optimum Currency Areas: Evidence for the United States, in: M.B. Canzonieri, V. Grilli and P.R. Masson (eds.), Establishing a Central Bank: Issues in Europe and Lessons from the U.S., Cambridge University Press.

vonKalckreuth, U. (2006), Financial Constraints and Capacity Adjustment: Evidence from a Large Panel of Survey Data, Economica, 73, 691-724.

vonKalckreuth, U. (2008), Financing Constraints, Firm-Level Adjustment of Capital and Aggregate Implications, Bundesbank Discussion Paper Series 1: Economic Studies, 11. 


\section{CESifo Working Paper Series}

for full list see www.cesifo-group.org/wp

(address: Poschingerstr. 5, 81679 Munich, Germany, office@cesifo.de)

2737 Hans Jarle Kind and Frank Stähler, Market Shares in Two-Sided Media Industries, July 2009

2738 Pamela Campa, Alessandra Casarico and Paola Profeta, Gender Culture and Gender Gap in Employment, August 2009

2739 Sebastian Gechert, Supplementary Private Health Insurance in Selected Countries: Lessons for EU Governments?, August 2009

2740 Leif Danziger, Endogenous Monopsony and the Perverse Effect of the Minimum Wage in Small Firms, August 2009

2741 Yan Dong and John Whalley, A Third Benefit of Joint Non-OPEC Carbon Taxes: Transferring OPEC Monopoly Rent, August 2009

2742 Valentina Bosetti, Carlo Carraro and Massimo Tavoni, Climate Change Mitigation Strategies in Fast-Growing Countries: The Benefits of Early Action, August 2009

2743 Christina Felfe, The Willingness to Pay for Job Amenities: Evidence from Mothers' Return to Work, August 2009

2744 Jörg Franke, Christian Kanzow, Wolfgang Leininger and Alexandra Väth, Effort Maximization in Asymmetric N-Person Contest Games, August 2009

2745 Bruno S. Frey and Paolo Pamini, Making World Heritage Truly Global: The Culture Certificate Scheme, August 2009

2746 Frank N. Caliendo, Is Social Security behind the Collapse of Personal Saving?, August 2009

2747 Caterina Liesegang and Marco Runkel, Corporate Income Taxation of Multinationals and Fiscal Equalization, August 2009

2748 Chrysovalantou Milliou and Apostolis Pavlou, Upstream Horizontal Mergers and Efficiency Gains, August 2009

2749 Rüdiger Pethig and Christian Wittlich, Interaction of Carbon Reduction and Green Energy Promotion in a Small Fossil-Fuel Importing Economy, August 2009

2750 Kai Carstensen, Oliver Hülsewig and Timo Wollmershäuser, Monetary Policy Transmission and House Prices: European Cross-country Evidence, August 2009

2751 Olaf Posch, Explaining Output Volatility: The Case of Taxation, August 2009 
2752 Beatrice Scheubel, Daniel Schunk and Joachim Winter, Don't Raise the Retirement Age! An Experiment on Opposition to Pension Reforms and East-West Differences in Germany, August 2009

2753 Daniel G. Arce, Dan Kovenock and Brian Roberson, Suicide Terrorism and the Weakest Link, August 2009

2754 Mario Larch and Wolfgang Lechthaler, Comparative Advantage and Skill-Specific Unemployment, August 2009

2755 Horst Raff and Nicolas Schmitt, Buyer Power in International Markets, August 2009

2756 Seppo Kari, Hanna Karikallio and Jukka Pirttilä, The Impact of Dividend Taxation on Dividends and Investment: New Evidence Based on a Natural Experiment, August 2009

2757 Mirco Tonin and Michael Vlassopoulos, Disentangling the Sources of Pro-social Behavior in the Workplace: A Field Experiment, August 2009

2758 Nicole Grunewald and Inmaculada Martínez-Zarzoso, Driving Factors of Carbon Dioxide Emissions and the Impact from Kyoto Protocol, August 2009

2759 Yu-Fu Chen and Michael Funke, Booms, Recessions and Financial Turmoil: A Fresh Look at Investment Decisions under Cyclical Uncertainty, August 2009

2760 Jan-Egbert Sturm and Jakob de Haan, Does Central Bank Communication really Lead to better Forecasts of Policy Decisions? New Evidence Based on a Taylor Rule Model for the ECB, August 2009

2761 Larry Karp, Sacrifice, Discounting and Climate Policy: Five Questions, August 2009

2762 Marianna Belloc and Samuel Bowles, International Trade, Factor Mobility and the Persistence of Cultural-Institutional Diversity, August 2009

2763 Charles Noussair and Fangfang Tan, Voting on Punishment Systems within a Heterogeneous Group, August 2009

2764 Birgit Bednar-Friedl and Karl Farmer, Internationally Coordinated Emission Permit Policies: An Option for Withdrawers from the Kyoto Protocol?, August 2009

2765 Pierre M. Picard and David E. Wildasin, Labor Market Pooling, Outsourcing and Labor Contracts, August 2009

2766 Stefan Voigt and Lorenz Blume, The Economic Effects of Federalism and Decentralization - A Cross-Country Assessment, August 2009

2767 David S. Jacks, Christopher M. Meissner and Dennis Novy, Trade Booms, Trade Busts, and Trade Costs, August 2009 
2768 Mario Jametti and Thomas von Ungern-Sternberg, Hurricane Insurance in Florida, August 2009

2769 Alessandro Balestrino, Kind of Black: The Musicians’ Labour Market in Italy, August 2009

2770 Yosr Abid Fourati and Cathal O’Donoghue, Eliciting Individual Preferences for Pension Reform, August 2009

2771 Christian Breuer and Chang Woon Nam, VAT on Intra-Community Trade and Bilateral Micro Revenue Clearing in the EU, August 2009

2772 Choudhry Tanveer Shehzad, Jakob De Haan and Bert Scholtens, Growth and Earnings Persistence in Banking Firms: A Dynamic Panel Investigation, August 2009

2773 Erdal Yalcin, Uncertain Productivity Growth and the Choice between FDI and Export, August 2009

2774 Klaus Abberger, Wolfgang Nierhaus and Shynar Shaikh, Findings of the Signal Approach for Financial Monitoring in Kazakhstan, September 2009

2775 Sascha O. Becker, Francesco Cinnirella and Ludger Woessmann, The Trade-off between Fertility and Education: Evidence from before the Demographic Transition, September 2009

2776 Thomas Aronsson and Erkki Koskela, Optimal Income Taxation, Outsourcing and Policy Cooperation in a Dynamic Economy, September 2009

2777 Joel Slemrod, Old George Orwell Got it Backward: Some Thoughts on Behavioral Tax Economics, September 2009

2778 Cagri Seda Kumru and Athanasios C. Thanopoulos, Social Security Reform and Temptation, September 2009

2779 Alessandro Bucciol and Roel M. W. J. Beetsma, Inter- and Intra-generational Consequences of Pension Buffer Policy under Demographic, Financial and Economic Shocks, September 2009

2780 Eduardo Strube and Marcelo Resende, Complementarity of Innovation Policies in the Brazilian Industry: An Econometric Study, September 2009

2781 Henry Tulkens and Vincent van Steenberghe, "Mitigation, Adaptation, Suffering": In Search of the Right Mix in the Face of Climate Change, September 2009

2782 Maria L. Loureiro, Anna Sanz-de-Galdeano and Daniela Vuri, Smoking Habits: Like Father, Like Son, Like Mother, Like Daughter, September 2009

2783 Momi Dahan, Tehila Kogut and Moshe Shalem, Do Economic Policymakers Practice what they Preach? The Case of Pension Decisions, September 2009 
2784 Eytan Sheshinski, Uncertain Longevity and Investment in Education, September 2009

2785 Nannette Lindenberg and Frank Westermann, How Strong is the Case for Dollarization in Costa Rica? A Note on the Business Cycle Comovements with the United States, September 2009

2786 Leif Danziger, Noncompliance and the Effects of the Minimum Wage on Hours and Welfare in Competitive Labor Markets, September 2009

2787 Gerlinde Fellner, Rupert Sausgruber and Christian Traxler, Testing Enforcement Strategies in the Field: Legal Threat, Moral Appeal and Social Information, September 2009

2788 Gabriel J. Felbermayr, Mario Larch and Wolfgang Lechthaler, Unemployment in an Interdependent World, September 2009

2789 Sebastian G. Kessing, Federalism and Accountability with Distorted Election Choices, September 2009

2790 Daniel Gros, Global Welfare Implications of Carbon Border Taxes, September 2009

2791 Louis N. Christofides, Michael Hoy and Ling Yang, The Gender Imbalance in Participation in Canadian Universities (1977-2005), September 2009

2792 Jan K. Brueckner and Robert W. Helsley, Sprawl and Blight, September 2009

2793 Vidar Christiansen and Stephen Smith, Externality-correcting Taxes and Regulation, September 2009

2794 John Beirne, Guglielmo Maria Caporale, Marianne Schulze-Ghattas and Nicola Spagnolo, Global and Regional Spillovers in Emerging Stock Markets: A Multivariate GARCH-in-mean Analysis, September 2009

2795 Rüdiger Pethig and Frieder Kolleß, Asymmetric Capital-Tax Competition, Unemployment and Losses from Capital Market Integration, September 2009

2796 Ngo Van Long, Horst Raff and Frank Stähler, Innovation and Trade with Heterogeneous Firms, September 2009

2797 Margit Osterloh and Bruno S. Frey, Research Governance in Academia: Are there Alternatives to Academic Rankings?, September 2009

2798 Thiess Buettner and Clemens Fuest, The Role of the Corporate Income Tax as an Automatic Stabilizer, September 2009 